\title{
OPEN EDUCATIONAL PRACTICES IN ROMANIAN UNIVERSITIES DURING THE EDUCATIONAL DISRUPTION
}

\author{
Diana Andone, Politehnica University of Timisoara, Gabriela Grosseck, West University of
} Timisoara, Carmen Holotescu, "Ioan Slavici” University of Timisoara, Romania

\begin{abstract}
The Covid-19 pandemic led to an unprecedented situation, when education worldwide moved online, leading to what is called Emergency Remote Teaching. Completed three months after the suspension of face-to-face activities in schools and universities, this paper aims to capture the actions taken in three Romanian universities, for the continuity of education in online environment. How prepared were the higher institutions in terms of infrastructure, teacher training, digital competences of teachers and students, open education strategy? What educational technologies have been used, what is the role of Open Educational practices, the integration of Open Educational Resources and Massive Open Online Courses? How were accessed, adopted and adapted the many international initiatives, projects and resources? What are the results of the studies already carried out on the efficiency of the actions taken? What can be done better until the return to the face-to-face activities, what are the lessons learned and how this knowledge will be applied for a better future? What current practices will have an impact on the teaching-learning activity, on the opening of education?
\end{abstract}

\section{Introduction}

While people were shutting the doors to their homes and countries were closing their borders, the virtual realm was opening up. The necessary social isolation measures have led to the disruption of school-based education for several months in most countries around the world. According to UNESCO, the maximum number of affected learners were at the beginning of April, almost 1.6 billion from 194 countries, representing $91.3 \%$ of total enrolled learners. In the second part of June, after a number of schools were reopen in a few countries, there are more than 1.1 billion learners, from 144 countries, meaning $67.7 \%$ of the total (UNESCO, 2020a). 
In March, just in a few days, pupils, students, teachers and all the other educational actors were forced to make a quick transition towards online learning and teaching. In fact, what we have experienced is an "emergency remote teaching" (ERT), which means an adjustment for a temporary period of time, that involves alternative ways of delivering instruction, fully remote teaching solutions "that would otherwise be delivered face-to-face or as blended or hybrid courses and that will return to that format once the crisis or emergency has abated" (Hodges et al., 2020).

Without an effective strategy to protect the opportunity to learn during this period, this disruption will cause severe learning losses for students. The continuity of the learning process for students, respectively support for students who lack the skills of independent learning should be ensured with priority (Reimers \& Schleicher, 2020).

\section{Romanian universities response}

On March 11, 2020, the Romanian Ministry of Education and Research (MER) has suspended the courses in all the schools, encouraging and supporting the continuation of the educational activities for 2.8 million pupils in online environment. Having autonomy, the same day, universities have stopped their face-to-face courses, the activity being continued as online courses on virtual learning platforms, for more than 500 thousand learners. Since then, there has been a high mobilization and collaboration between teachers, students, parents, ministry and the whole society in supporting this Emergency Remote Education process (Holotescu et al., 2020).

Romania was not found unprepared, having a good infrastructure, teacher training, Open Educational Resources (OER) repositories created in previous projects and an active Open Education movement, but with problems related to Internet connection in rural areas, to the level of teachers' digital skills, and also to software platforms available in schools (Grosseck, Holotescu, \& Andone, 2020).

For most universities, the educational programs continue on their online learning platforms. Below there are the initiatives undertaken by three of the most active universities in the area of Open Education, which implemented open and blended learning approaches, and continuous teachers training during the past years (Holotescu, Andone, \& Grosseck, 2016). To overcome the challenges of moving online the whole process of teaching and learning, to keep students motivated and engaged, effective pedagogical approaches were applied, using Open Educational Practices (OEP) and Resources (OER), also integrating Massive Open Courses (Wiley \& Hilton, 2018; Huang et al., 2020). 


\section{Politehnica University of Timisoara}

All the courses of Politehnica University of Timisoara (UPT) are run online on the Virtual Campus platform (http://cv.upt.ro), implemented on Moodle, and accompanied by a mobile application (Holotescu, Vasiu, \& Andone, 2018). UPT has also a MOOC platform (http://unicampus.ro) with open courses which are used for training or integration in traditional courses (Vasiu \& Andone, 2014).

The university has developed a specific methodology for this period, since the first week of the lockdown. Most of the teachers acquired already skills and knowledge for online/blended learning during the national DidaTec project (Training in blendedlearning and new educational technologies for university academic staff) or in the continuous training program offered by the eLearning Center (CeL) (http://elearning.upt.ro). In this period, CeL runs daily live sessions for teachers, in order to support them and to improve their skills for online courses developing and facilitation, and for OERs and MOOCs integration, in a process consisting in the phases of identification, validation, integration and assessment (Andone et al., 2015). The webinars are registered and uploaded with CC licenses on the CeL's YouTube channel for future reuse. At the beginning with April, the university started to organize online exams for all study programs and the admission will be held online too.

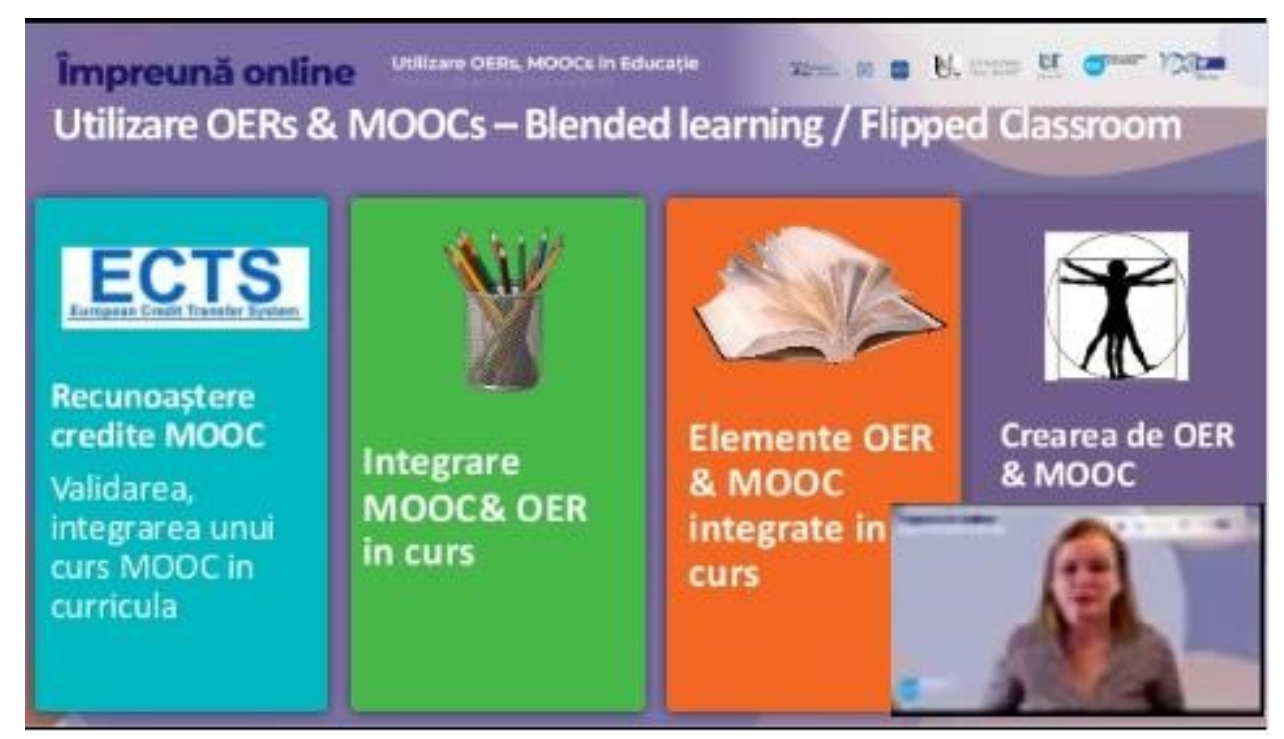

Figure 1. \#togetheronline workshop related to OER and MOOC integration

CeL runs also weekly national webinars for teachers and students, in the series "From Campus to Online Learning" \#togetheronline (https://elearning.upt.ro/ro/impreunaonline/), the first one being organized on April 15: "We aim to succeed in getting out of the individualistic paradigm and to collaborate as much as possible, between us, those in the Romanian educational environment, to find out ideas, experiences and solutions that each of us has tried to apply together". Therefore, there are shared valuable experiences about 
organizing the educational process at the level of universities and departments, about strategies, open practices, applications and platforms for teaching, assessment, evaluation, collaboration, the insights being brought by teachers, students and managers (Figure 1). The presentations and videos are published on Slideshare, Facebook, Youtube and IGTV, with open licenses, while the participants receive open badges.

\section{West University of Timisoara}

West University of Timisoara (WUT, http://www.uvt.ro) is well equipped with the technology needed for online learning, thus all the courses are run online using G-Suite and Moodle. WUT created a special digital repository (https://resurse.e-uvt.ro/) with a variety of educational resources, including textbooks, course materials, video training. On the other hand, teachers and students use Google Shared Drive, to list the Open Textbooks and OERs they use. The academic community members use Meet, Zoom or Webex for online classes. The sessions are recorded and uploaded for use and reuse by students and teachers. Students also have the opportunity to participate in training sessions organized by the Center for Counselling and Career Orientation (CCCO) to acquire knowledge about online learning.

In order to engage and motivate students, the MOOC-based teaching method has been successfully used during the past three years (https://west-universitytimisoara.teachable.com) (Figure 2). Since 2015, WUT has supported open education (http://novamooc.uvt.ro) and has included MOOCs in the program of complementary disciplines, which generate transversal competencies (TCD - http://dct.uvt.ro). They are accessible to all students, from all majors. For example, "Learning English with Technology" was first created as a pilot SPOC (Small Private Online Course) and included for the first time in the TCD program during the second semester of the 2017/2018 academic year, the course being active since then (Bran \& Grosseck, 2019). Another initiative set up four years ago regards the integration of OERs and MOOCs in particular courses. The students who participate in different MOOCs, with topics related to the curricula, receive credits for their activities in such courses (Holotescu \& Grosseck, 2018). For example, in the transversal discipline "Digital Storytelling”, the teacher includes parts of the course "Pixar in a Box" from Khan Academy (https://www.khanacademy.org/partner-content/pixar/storytelling) in some of the learning units. 
Cursuri disponibile

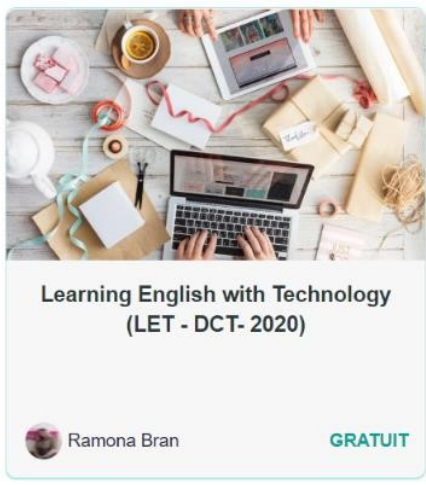

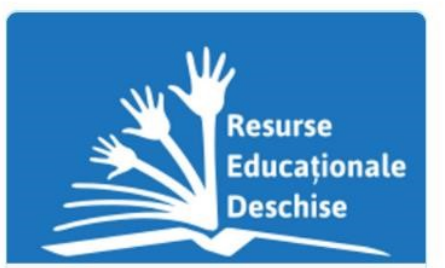

Resurse Educaționale Deschise Inițiere pentru profesori

Gabriela Grosseck

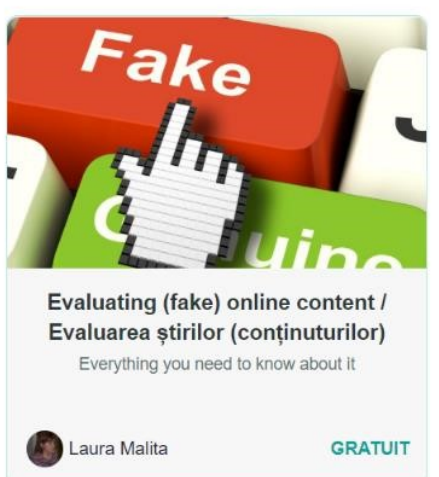

Figure 2. MOOCs offered by WUT

For the purpose to find the best ways to interact with students and provide quality online education, WUT has consistently applied questionnaires to both students and teachers. Moreover, WUT is the first higher education institution that organizes an online postgraduate program for training and continuous professional development of preuniversity teachers, focused on digital and online teaching, learning and assessment activities.

In order to encourage students, WUT posts inspirational messages and photos on social media, Facebook pages and Instagram (social emotional campaigns, \#uvt happywall and \#stamAcasa). WUT also has developed some specific solutions for managing anxiety: a site that lists prevention methods http://masuridepreventie.uvt.ro) and webinars offered by the CCCO. Simultaneously, the Department of Psychology has started a weekly publication, "Pastila de psihologie" (The psychological tablet), which is distributed to entire academic community and the general public through Facebook and the department's blog (https://www.psihologietm.ro/\#blog).

\section{"Ioan Slavici" University of Timisoara}

The teachers of "Ioan Slavici" University of Timisoara run the courses using the university platform (http://islavici.ro/softstudenti) and different free online learning applications (Chirila \& Chirila, 2020; Maris et al., 2018), being supported by the Center for Open Education and Blockchain (http://www.islavici.ro), and also by their colleagues by adopting co-teaching or peer-mentoring practices.

The university platform has features for multimedia content, synchronous and asynchronous interaction between students, teachers and invited lecturers, and also an open repository of OERs produced by students and teachers, for future reuse in university, but also by the larger academic community. 
Following an initiative started seven years ago, teachers have participated in international MOOCs for improving their knowledge in their own area of expertise and for improving their competencies and skills for adopting new models of open educational practices (Holotescu, Andone, \& Grosseck, 2016).

Thus, especially during the pandemic crises, many of the university courses have followed open educational practices for OERs and MOOCs integration (Holotescu et al., 2014). Therefore, the students consult part of the content of a number of MOOCs and also participate in their social activities (assignments, discussions, peer evaluation). The complex task of the teacher is to synchronize the activities of his or her own course with those of MOOCs, proving support, feedback, additional OERs, moderating and nurturing the local learning community (Figure 3).

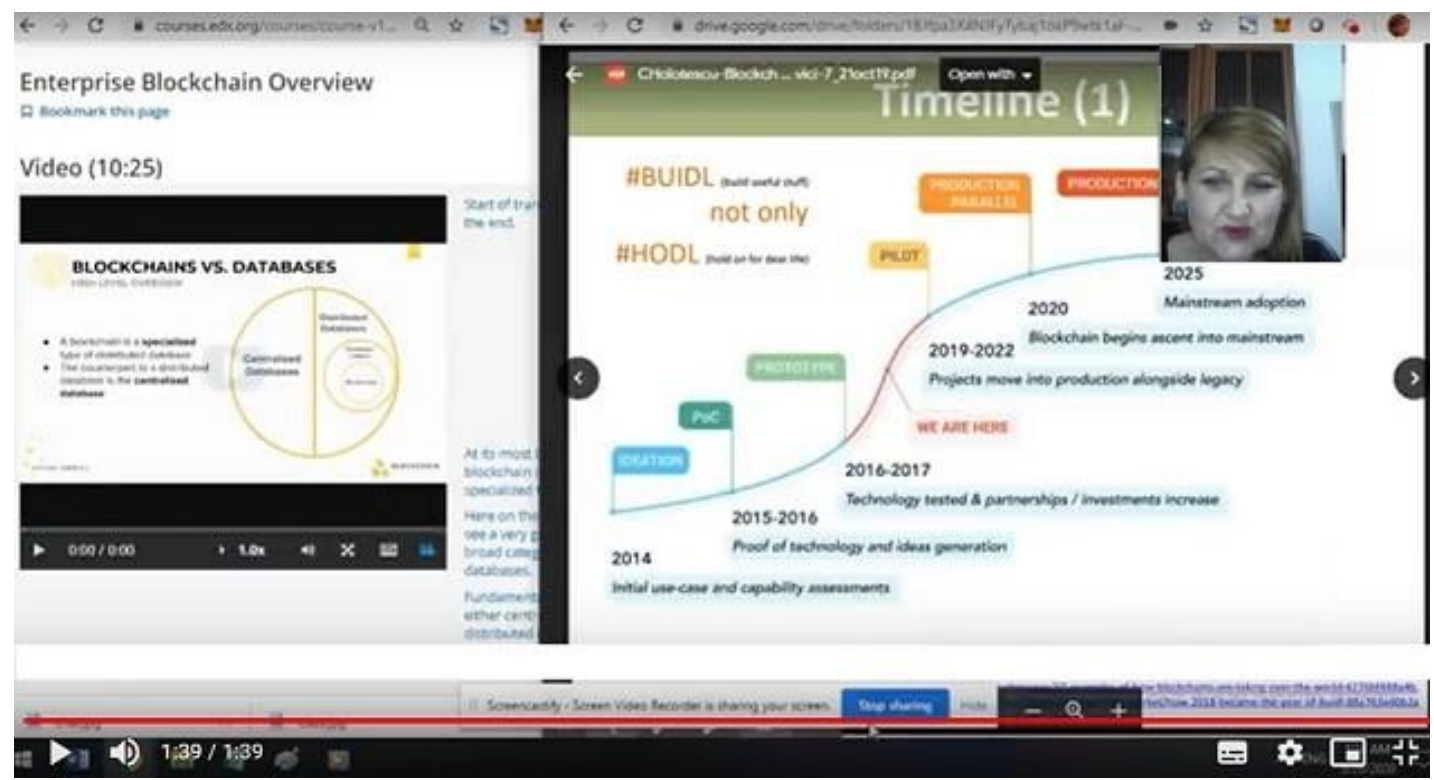

Figure 3. Video lecture in an online course with MOOC integration

Students have a high autonomy in assessing their own learning needs for choosing the MOOCs in which to participate in order to deepen the course topics, are exposed to high quality materials created with top educational technologies, to collaboration in global learning communities and to a broader range of experiences than those to which they otherwise might have access.

\section{Discussions}

In these three months of lockdown, teachers have learned and applied many new things about open and blended education, tools and applications, have improved their digital skills, acquiring maybe more than in previous formal face-to-face training sessions. They have self-assessed their training needs, participated in efficient and active communities, learning together with their peers, making important steps towards becoming Open Scholars. 
Students found a favourable ground to become more creative, more active, more collaborative, their ideas of organizing the learning being taken into consideration to a greater extent by teachers, thus becoming their real partners in the teaching-learning process.

Both students and teachers should be more aware and use the large number of valuable digital resources and participate in the MOOCs about online learning, made now freely accessible worldwide by companies, publishers, libraries, universities, museums, and international and European organizations (WHO, UNESCO, OECD, OERu, Google, Europa.eu, FutureLearn, Coursera, etc.). Under these circumstances, everyone could become a long-life learning and informed learner.

Nobody knows when this crisis will end, when we'll be able to return to normal, and what the new normal means.

The open strategies adopted by the three universities and presented in the article were recognized as successful use-cases for Open Education and were quoted in the UNESCO Guidance about OEPs, already translated and published in Romanian, to facilitate the adoption of open educational practices by other teachers and institutions (Huang et al., 2020). Having open education strategies implemented during the past years, these universities could have a smooth transition to online teaching and learning, and could contribute with studies, events, OEPs, new developed OERs to the larger academic community of practice.

We believe that a real strategy for the improvement of the educational system is needed, following the experience and lessons learnt during this still ongoing crisis: online learning recognition, better infrastructure ensuring the access to quality education, a national online learning platform, MOOC and OER integration in formal learning, digital credentials on Blockchain for students and teachers' participation in MOOCs on different platforms (Miclea, 2020; Holotescu \& Grosseck, 2018; Holotescu \& Vasiu, 2020).

Education has to be more centred on students, has to use more the technology, in a correct, flexible and efficient way. More quality and effective training programs for teachers to be organized online or in a blended manner. Also education should become more open, should use, integrate, produce quality OERs and MOOCs, should use the blended and flipped approaches, and collaboration between teachers and institutions should become more global. 
Thus, we should rethink the role of a resilient and quality Education at all levels:

- Institutional level

- motivate teachers to learn continuously - in (in)formal programs, MOOCs;

- adopt open educational practices/blended learning, integrate OERs and MOOCs - National Level;

- implement programs for infrastructure, connectivity;

- promote Open Education principles, OER repositories, as reservoirs of resilience (Kanwar \& Daniel, 2020);

- establish transparent public-private partnerships - European level;

- recovery instrument NextGenerationEU (EC, 2020): supporting distance learning and digital skills development;

- projects for opening up education, micro-credentials for formal recognition of different learning paths (MOOCs);

- International level

- collaboration for sharing best practices, for communities of practice of teachers and policy makers;

- collaboration for adopting UNESCO Recommendations for OER/Dynamic Coalition of OER (UNESCO, 2020b).

\section{References}

Andone, D., Mihaescu, V., Ternauciuc, A., \& Vasiu, R. (2015). Integrating MOOCs in traditional higher education. Proceedings of the Third European MOOCs Stakeholder Summit, 71-75.

Bran, R., \& Grosseck, G. (2019). Speaking about SPOC: Can a Small Private Online Course (SPOC) Be a Viable Solution for Teaching English? Buletinul Științific al Universității Politehnica Timișoara, Seria Limbi Moderne, 18(1-2), 142-157.

Chirila, O. S., \& Chirila, C. B. (2020, May). The Data Structures for e-Learning (DSEL) Platform. Paper presented at the $16^{\text {th }}$ International Conference eLSE, Bucharest.

European Commission. (June 2020). EC Communication on the recovery instrument NextGenerationEU. Retrieved from https://tinyurl.com/nextgenerationeu.

Grosseck, G., Holotescu, C., \& Andone, D. (2020). Open Educational Resources in Romania. In R. Huang, D. Liu, A. Tlili, Y. Gao, R. Koper (Eds.), Current State of Open Educational Resources in the "Belt and Road" Countries. Lecture Notes in Educational Technology. Springer, Singapore.

Hodges, C., Moore, S., Lockee, B., Trust, T., \& Bond, A. (2020, March 27). The Difference between Emergency Remote Teaching and Online Learning. EDUCAUSE Review 
[Blog post]. Retrieved from https://er.educause.edu/articles/2020/3/the-differencebetween-emergency-remote-teaching-and-online-learning

Holotescu, C., Andone, D., \& Grosseck, G. (2016). MOOCs strategies in Romanian universities. In D. Jansen, \& L. Konings (Eds.), European policy response on MOOC opportunities. Maastricht: EADTU Publisher. Retrieved from https://home.eadtu.eu/news/111-report-europeanpolicy-response-on-moocopportunities

Holotescu, C., \& Grosseck, G. (2018). Towards a MOOC-related Strategy in Romania. BRAIN. Broad Research in Artificial Intelligence and Neuroscience, 9, 99-109.

Holotescu, C., Grosseck, G., Andone, D., Gunesch, L., Constandache, L., Nedelcu, V.D., Ivanova, M. \& Dumbraveanu, R. (2020). Romanian Educational System Response during the Covid-19 Pandemic. Proceedings of the $16^{\text {th }}$ International Scientific Conference "eLearning and Software for Education" Bucharest, April 23-24, 2020. 3, 1120. doi: 10.12753/2066-026X-20-171.

Holotescu, C., Grosseck, G., Cretu, V., \& Naaji, A. (2014). Integrating MOOCs in Blended Courses. Proceedings of the $10^{\text {th }}$ International Conference eLSE, Bucharest, 4, 243-250.

Holotescu, V., Andone, D., \& Vasiu, R. (2018). Developing hybrid mobile applications for learning. Proceedings of the 2018 International Symposium on Electronics and Telecommunications (ISETC). IEEE. 1-4.

Holotescu, V., \& Vasiu, R. (2020). Challenges and Emerging Solutions for Public Blockchains. BRAIN. Broad Research in Artificial Intelligence and Neuroscience, 11(1), 58-83.

Huang, R., Liu, D., Tlili, A., Knyazeva, S., Chang, T. W., Zhang, X., Burgos, D., Jemni, M., Zhang, M., Zhuang, R., \& Holotescu, C. (2020). Guidance on Open Educational Practices during School Closures: Utilizing OER under COVID-19 Pandemic in line with UNESCO OER Recommendation. Beijing: Smart Learning Institute of Beijing Normal University.

Kanwar, A., Daniel, J. (2020). Report to Commonwealth Education Ministers: From Response to Resilience. COL Report. Retrieved from https://tinyurl.com/colreportresilience

Maris, S., Maris, S. A., Dungan, L., \& Slavici, T. (2018). Re-shaping education: Role of internet resources in increasing the efficiency of the educational process. BRAIN. Broad Research in Artificial Intelligence and Neuroscience, 9(1), 132-137.

Miclea, M. (2020). Școala de mâine. Edupedu. Retrieved from https://www.edupedu.ro/mircea-miclea-scoala-demaine 
Reimers, F. M., \& Schleicher, A. (2020). Education Responses to COVID-19: Embracing Digital Learning and Online Collaboration. Retrieved from https://bit.ly/39hDURb.

UNESCO. (2020a). COVID-19 Educational Disruption and Response. Retrieved from https://en.unesco.org/themes/education-emergencies/coronavirus-school-closures.

UNESCO. (2020b). Dynamic Coalition for OER. Retrieved from https://en.unesco.org/themes/building-knowledgesocieties/oer/dynamic-coalition.

Vasiu, R., \& Andone, D. (2014). OER and MOOCs - The Romanian experience. Proceedings of the Web and Open Access to Learning (ICWOAL), 2014 International Conference. IEEE. 1-5.

Wiley, D., \& Hilton III, J. L. (2018). Defining OER-enabled pedagogy. International Review of Research in Open and Distributed Learning, 19(4). 